\title{
DATA MINING PEMBENTUKAN POLA PENGGUNAAN ALAT KONTRASEPSI DENGAN METODE ASSOCIATION RULE
}

\author{
${ }^{1}$ Elisa Hafrida ${ }^{\bigotimes},{ }^{1}$ Febrina Sari, ${ }^{1}$ Desyanti, ${ }^{2}$ Siti Nurjannah \\ ${ }^{1}$ Sekolah Tinggi Teknologi Dumai, Indonesia \\ ${ }^{2}$ Akademi Keperawatan Sri Bunga Tanjung Dumai, Indonesia \\ Email: hafridae@yahoo.com
}

DOI: https://doi.org/10.46880/jmika.Vol4No2.pp186-191

\begin{abstract}
Continuous use of contraceptives is a factor influencing the success of the family planning program. As is well known, contraceptives are not necessarily suitable for everyone's condition, therefore women must be able to determine what contraception is suitable for themselves. The problem is that many women find it difficult to decide what contraceptive method to use, apart from a lack of knowledge and information, there is no concept $/$ pattern for choosing a contraceptive device. The purpose of this study is to find patterns of contraceptive use using the Data Mining Association Rule method. The results of the performance of the Apriori Algorithm produce a combination pattern that describes the set of frequent item sets with the highest confidence value, namely $90 \%$ In the Rule, if the injectable contraceptive device is 3 months, then the mother's age is 17-35 years. The pattern that is formed is the result of concept formulation, so that this pattern can be used as a reference for prospective acceptors in determining the choice of contraceptives suitable for use.
\end{abstract}

Keyword: Knowledge Extraction, Association Patterns, Acceptors, Contraception.

\begin{abstract}
ABSTRAK
Penggunaan Alat Kontrasepsi secara berkelanjutan merupakan faktor yang mempengaruhi keberhasilan Program KB. Seperti yang diketahui alat kontrasepsi belum tentu cocok dengan kondisi setiap orang, oleh karenanya Para wanita harus bisa menentukan alat kontrasepsi apa yang cocok untuk dirinya. Permasalahannya banyak para wanita sulit untuk memutuskan alat kontrasepsi apa yang akan digunakan, selain kurangnya pengetahuan dan informasi, belum tersedianya konsep/pola untuk pemilihan alat kontrasepsi. Tujuan dari penelitian ini adalah menemukan pola penggunaan alat kontrasepsi dengan menggunakan metode data mining association rule. Hasil kinerja algoritma apriori menghasilkan pola kombinasi yang menggambarkan kumpulan frequent item set dengan nilai confidence tertinggi yakni sebesar $90 \%$ pada rule jika alat kontrasepsi suntik 3 bulan maka usia ibu 17-35 tahun. Pola yang terbentuk merupakan hasil formulasi konsep, sehingga pola ini dapat dijadikan acuan bagi para calon akseptor dalam menentukan pilihan alat kontrasepsi yang cocok untuk digunakan.
\end{abstract}

Kata Kunci: Ekstraksi Pengetahuan, Pola Asosiasi, Akseptor, Kontrasepsi.

\section{PENDAHULUAN}

Alat Kontrasepsi merupakan faktor penting dalam mensukseskan program keluarga berencana. Selain untuk menurunkan angka kelahiran pemakaian alat kontrasepsi juga untuk mewujudkan demografi yang berkualitas. Hasil survei RPJMN 2017, penggunaan alat kontrasepsi menurun, yakni angka 59,7\%. (BkkbN, 2017). Hal ini terjadi karena akseptor tidak lagi menggunakan alat kontrasepsi, dengan berbagai alasan salah satunya adalah alat kontrasepsi yang digunakan tidak cocok atau memberikan efek samping. Jadi setiap wanita harus mampu memutuskan alat kontrasepsi apa yang akan digunakan. Permasalahannya banyak wanita mengalami kesulitan untuk memutuskan alat kontrasepsi apa yang sesuai untuk digunakan. Saat ini para akseptor masih melakukan pilihan berdasarkan pengalaman orang lain, pihak terkait seperti puskesmas sendiri belum memiliki konsep atau aturan tertentu dalam menentukan alat kontrasepsi yang sesuai untuk digunakan oleh akseptor. Berdasarkan permasalahan diatas maka perlu adanya penerapan sebuah metode guna memperoleh pola atau aturan penggunaan alat kontrasepsi. Tujuan penelitian adalah menghasilkan pola atau aturan penggunaan alat kontrasepsi dengan cara mengimplementasikan metode Data Mining Association Rule, karena Data mining akan menggali informasi dari data yang berjumlah besar, sedangkan teknik untuk mendapatkan aturan atau pola dari kombinasi item 
diggunakan Algoritma Asosiasi. Aturan/pola yang terbentu akan membantu akseptor dalam memilih alat kontrasepsi yang akan digunakan. dan menjaga keberlangsungan penggunaannya.

Penelitian terkait tentang Penggunaan Alat Kontrasepsi dan Data Mining yang menjadi acuan dalam penelitian ini, dilakukan oleh (Andria, 2013), meneliti tentang Faktor yang Mempengaruhi PUS Tidak Menggunakan Alat Kontrasepsi. Hasil penelitiannya menunjukkan 20 orang atau sebesar 80\% Akseptor mengalami efek samping dari penggunaan alat kontrasepsi. Penelitian berikutnya dilakukan (Hasnani, 2019), meneliti tentang Faktor yang berpengaruh dalam pemilihan Alat Kontrasepsi Suntik. Hasilnya diperoleh pengetahuan dan sosial ekonomi berpengaruh namun pendidikan akseptor tidak memiliki pengaruh.

Sedangkan penelitian terkait dengan penerapan Data Mining Association Rule dalam pembentukan pola teleh dilakukan oleh (Safii \& Trydillah, 2019). tentang Pembentukan Pola Pembelian Obat, hasil terbentuknya 2 itemset obat yang dijadikan pedoman oleh karyawan untuk menata obat tersebut secara bersamaan. Selanjutnya penelitian dilakukan oleh (Agustin \& Muharmi, 2020), dengan tujuan Menentukan Pola Penyebab Gelandangan Dan Pengemis. hasil penelitian menunjukkan yang sering mengemis adalah usia Remaja Akhir, Dewasa Awal dan Dewasa Akhir.

Berdasarkan Literatur Review inilah peneliti tertarik untuk melakukan penelitian dengan menggabungkan dua bidang ilmu yakni kesehatan dan Teknik Informatika. Implementasi metode Data Mining Association Rule akan menghasilakan pola atau aturan asosiasi dari data transaksi akseptor di Puskesmas Dumai Barat.

\section{METODE PENELITIAN}

\section{Data Mining}

Data mining dapat diistilahkan sebagai kegiatan menguraikan penemuan pengetahuan didalam kumpulan data yang jumlahnya besar (Kusrini, 2009). Guna mendapatkan informasi dan pengetahuan yang bermanfaat dari banyaknya data yang tersimpan pada database Data mining menggunakan beberapa teknik seperti matematika, machine learning dan teknik statistik. (Mardiah, 2019).

Data mining merupakan cara menemukan hubungan yang berarti, dari sekumpulan data yang terdapat pada media penyimpanan, dengan memanfaatkan sejumlah teknik pengenalan pola, salah satu teknik yang dapat digunakan adalah teknik matematika. (Sari \& Saro, 2018).

Data mining adalah kegiatan iteratif dan interaktif guna mendapatkan aturan, pola atau model baru yang dapat dipertanggung jawabkan kebenarannya serta memberikan manfaat bagi pengambil keputusan pada masa yang akan datang. (Syahdan \& Sindar, 2018). Fungsi utama dari penambangan data yaitu mengekstrak pola data yang tersimpan dengan menerapkan berbagai metode dan algoritma (Sari, 2017).

\section{Algoritma Apriori}

Association rule mining adalah teknik data mining yang dapat dimanfaatkan untuk penemuan sejumlah aturan atau kombinasi item atau frequent itemset. Pengetahuan yang dihasilkan dari fungsi aturan asosiasi ini berbentuk if...then atau jika...maka. (Desyanti \& Sari, 2019).

Ada dua metodologi dasar dalam analisa asosiasi:

1. Analisis Pola Frekuensi Tinggi. Tahapan ini adalah proses menemukan kombinasi itemset yang sesuai dengan nilai support terkecil yang telah ditentukan. Rumus yang digunakan untuk memperoleh nilai support sebagai berikut:

$$
\text { Support }(A)=\frac{\sum \text { Transaksi Mengandung A }}{\sum \text { Transaksi }} \times 100 \%
$$

Jika itemset lebih dari satu maka untuk memperoleh nilai support digunakan rumus berikut:

Support $(A, B)=\frac{\sum \text { Transaksi Mengandung } A \text { dan } B}{\sum \text { Transaksi }} \times 100 \%$

Setelah frekuensi itemset ditemukan maka dilanjutkan dengan pembentukan Pola Asosiasi atau Aturan keterkaitan yang memenuhi syarat (Parhusip, 2019).

2. Pembentukan Aturan Assosiatif, didasari dari nilai itemset yang memenuhi support terkecil dilanjutkan ke langkah berikutnya yakni mencari aturan asosiasi dengan memperhatikan syarat nilai terkecil dari nilai confidence. Untuk memperoleh nilai confidence digunakan rumus berikut:

Confidence $P(B \mid A)=\frac{\sum \text { Transaksi Mengandung Adan } B}{\sum \text { Transaksi Mengandung } A} \times 100 \%$ 
Kuatnya ketertarikan antara satu item dengan item yang lain dapat dilihat dari besarnya nilai confidence.

Penjelasan dari setiap tahapan penelitian yang akan dilakukan mulai dari awal hingga penelitian berakhir, akan digambarkan dalam bentuk kerangka kerja berikut ini.

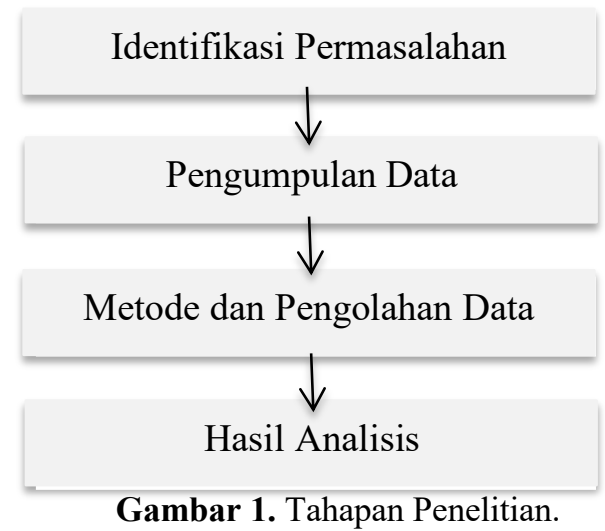

Dari gambar 1 dapat dijelaskan setiap langkah dari penelitian yakni :

1. Identifikasi Permasalahan

Permasalahan yang teridentifikasi adalah para calon akseptor mengalami kesulitan dalam menentukan alat kontrasepsi yang sesuai untuk digunakan, sampai saat ini penggunaan alat kontrasepsi ditentukan oleh calon akseptor, berdasarkan informasi yang diperoleh dari bidan atau dokter.

2. Pengumpulan Data

Data yang digunakan untuk penelitian berupa data primer hasil observasi dan wawancara dengan calon akseptor dan pihak Puskesmas Dumai Barat. Data sekunder diperoleh dari kajian beberapa artikel, buku dan jurnal terkait dengan penelitian.

3. Metode dan Pengolahan Data

Data yang akan diolah menggunakan metode Data Mining diperoleh dari database Puskesmas Dumai Barat, berupa data akseptor aktif pengguna alat kontrasepsi. Data ini tersedia tersedia dalam bentuk Ms.Excel kemudian diolah menggunakan dengan Algoritma Apriori. Pengolahan data melibatkan beberapa variabel pendukung. untuk memperoleh pola kombinasi atau aturan asosiasi berdasarkan data yang sering muncul atau frequent itemset.

4. Hasil Analisis

Melakukan seleksi terhadap hasil pengolahan data, dengan menampilkan seluruh data yang sesuai nilai min support dan nilai min confidence yang telah ditentukan, hasil akhir berupa rule atau aturan asosiasi yang sesuai dengan ketetapan Algoritma Apriori.

\section{HASIL DAN PEMBAHASAN}

Proses Analisis Association rule mining merupakan teknik Data Mining yang memiliki tahapan sebagai berikut:

\section{Pembersihan Data}

Data yang digunakan dalam penelitian ini berasal dari Puskesmas Dumai Barat. Data pengguna Alat Kontrasepsi Aktif yang ada di Puskesmas Dumai Barat berbentuk Ms.Excel adapun total data awal berjumlah 250 data. Pembersihan data perlu dilakukan karena ada beberapa data yang tidak lengkap, Setelah dilakukan proses pembersihan data menjadi 218 data.

2. Integrasi Data

Penelitian ini tidak memerlukan integrasi data atau penggabungan dari beberapa database karena data yang digunakan berbantuk tebel yang diambil dari aplikasi Ms.Excel.

\section{Seleksi Data}

Proses seleksi data sangat perlu untuk dilakukan guna memilih atribut yang benar dan berkaitan dengan pokok permasalah yang akan dibahas, semula terdapat 12 atribut pada data awal setelah dilakukan seleksi menjadi 3 atribut yakni Usia, Pendidikan dan Jenis Alat Kontrasepsi.

\section{Trasformasi Data}

Proses transformasi untuk atribut Usia, Pendidikan dilakukan dengan merubah data dalam bentuk kuantitatif menjadi kualitatif. Tabel 1 dan 2 merupakan proses trasformasi data (gambar), dan/atau bagan.

Tabel 1. Hasil Transformasi Usia

\begin{tabular}{|c|c|}
\hline Kategori & Keterangan \\
\hline $17-35$ & Menjarangkan Kehamilan \\
\hline$>35$ & Menunda Kehamilan \\
\hline
\end{tabular}

Tabel 2. Hasil Transformasi Pendidikan

\begin{tabular}{|c|c|}
\hline Kategori & Keterangan \\
\hline SD, SMP Sederajat & Rendah \\
\hline SMA Sederajat & Menengah \\
\hline Diploma, Sarjana & Tinggi \\
\hline
\end{tabular}

\section{Analisa Pola Frekuensi Tinggi}

Merupakan proses menemukan kombinasi item yang terdapat pada Tabel Data transaksi pengguna alat kontrasepsi dengan jumlah kemunculan data yang lebih sering muncul. Tabel 3 merupakan data transaksinya. 
Tabel 3. Data Transaksi Penggunaan Alat Kontrasepsi

\begin{tabular}{|c|l|}
\hline Akseptor & \multicolumn{1}{c|}{ Transaksi } \\
\hline 1 & Menunda, Menengah, Pil \\
\hline 2 & Menjarangkan, Rendah, Pil \\
\hline 3 & Menjarangkan, Rendah, Pil \\
\hline 4 & Menjarangkan, Tinggi, Suntik 3 Bulan \\
\hline 5 & Menjarangkan, Tinggi, Suntik 3 Bulan \\
\hline 6 & Menunda, Rendah, Pil \\
\hline 7 & Menunda, Tinggi, Pil \\
\hline 8 & Menjarangkan, Tinggi, Suntik 3 Bulan \\
\hline 9 & Menjarangkan, Tinggi, Suntik 3 Bulan \\
\hline 10 & Menjarangkan, Rendah, Pil \\
\hline Sampai dengan transaksi ke 218 \\
\hline 218 & Menunda, Menengah, Implan 2 Batang \\
\hline
\end{tabular}

Sebelum melakukan penyelesaian menggunakan Algoritma dengan Association Rule langkah awalnya adalah menentukan besaran $(\Phi)$, kemudian menetapkan nilai support dan confidence. Besaran yang digunakan untuk penelitian ini adalah $\Phi$ $=25$, Support $=30 \%$ dan Confidence $=70 \%$. Berdasarkan tabel 3. maka diperoleh jumlah kemunculan/frekuensi untuk 1 itemset yang memenuhi besaran $\Phi=25$. kemudian dilakukan proses perhitungan nilai support yang memenuhi nilai minimum $30 \%$, hasil perhitungan dapat di lihat pada tabel berikut.

Tabel 4. Frekuensi dan Support 1 Itemset

\begin{tabular}{|l|c|c|}
\hline 1 Itemset & $\mathbf{F}_{\mathbf{1}}$ & Support \\
\hline Menjarangkan & 164 & $75 \%$ \\
\hline Menunda & 54 & $25 \%$ \\
\hline Rendah & 90 & $41 \%$ \\
\hline Menengah & 35 & $16 \%$ \\
\hline Tinggi & 93 & $42 \%$ \\
\hline Pil & 90 & $41 \%$ \\
\hline Kondom & 6 & $3 \%$ \\
\hline IUD Cut 380A & 7 & $3 \%$ \\
\hline Implan 2 Batang & 22 & $19 \%$ \\
\hline Suntik 1 Bulan & 4 & $2 \%$ \\
\hline Suntik 3 Bulan & 89 & $40 \%$ \\
\hline
\end{tabular}

Dari tabel di atas transaksi 1 Itemset, yang memenuhi besar dari $\Phi=25$ dan minimum Support $30 \%$ adalah sebagai berikut :

$\mathrm{F}_{1}=\quad\{\{$ Menjarangkan $\}$

$\{$ Rendah\}

$\{$ Pil $\}$

\{Kondom\}

\{Suntik 3 Bulan\}\}

Untuk pembentukan Pola 2 itemset, maka disusunlah beberapa Himpunan yang mungkin terbentuk. Kemungkinan himpunan yang terbentuk adalah sebagai berikut :

\section{$\mathrm{F}_{2}=\quad\{\{$ Menjarangkan,Rendah $\}$ \\ \{Menjarangkan,Pil\} \\ \{Menjarangkan,Kondom\} \\ \{Menjarangkan,Suntik 3 Bulan\} \\ \{Rendah,Kondom\}}

\{Rendah,Suntik 3 Bulan\} \}

Himpunan $\{$ Pil $\}$, \{Kondom\}, \{Suntik 3 Bulan\} tidak dikombinasikan karena ketiga item tersebut merupakan 1 kategori yakni kategori Alat Kontrasepsi.

Hasil perhitungan Support untuk 2 item dapat dilihat pada tabel dibawah.

Tabel 5. Frekuensi dan Support 2 itemset

\begin{tabular}{|l|c|c|}
\hline 2 Itemset & $\mathbf{F}_{\mathbf{2}}$ & Support \\
\hline $\begin{array}{l}\text { Menjarangkan,Re } \\
\text { ndah }\end{array}$ & 77 & $35 \%$ \\
\hline Menjarangkan,Pil & 74 & $34 \%$ \\
\hline $\begin{array}{l}\text { Menjarangkan,Ko } \\
\text { ndom }\end{array}$ & 67 & $31 \%$ \\
\hline $\begin{array}{l}\text { Menjarangkan,Su } \\
\text { ntik 3 Bulan }\end{array}$ & 80 & $37 \%$ \\
\hline Rendah, Kondom & 55 & $25 \%$ \\
\hline $\begin{array}{l}\text { Rendah,Suntik 3 } \\
\text { Bulan }\end{array}$ & 54 & $25 \%$ \\
\hline
\end{tabular}

Berdasarkan Tabel 5, pola 2 itemset yang memenuhi syarat dari Support adalah :

$F_{2}=\quad\{\{$ Menjarangkan, Rendah $\}$

\{Menjarangkan,Pil\}

\{Menjarangkan,Kondom\}

\{Menjarangkan,Suntik 3 Bulan\}\}

Kombinasi itemset $\mathrm{F}_{2}$, kemudian digabung menjadi kandidat 3-itemset. Adapun itemset baru yaitu:

$\mathrm{F}_{3}=\{$ Menjarangkan,Rendah,Pil $\}$

\{Menjarangkan,Rendah,Suntik 3 Bulan\}

Hasil perhitungan Support untuk 3 item terdapat di table 6 .

Tabel 6. Frekuensi dan Support 3 itemset

\begin{tabular}{|l|c|c|}
\hline \multicolumn{1}{|c|}{ 3 Itemset } & $\mathbf{F}_{\mathbf{3}}$ & Support \\
\hline Menjarangkan, Rendah, Pil & 47 & $22 \%$ \\
\hline $\begin{array}{l}\text { Menjarangkan, Rendah, Suntik 3 } \\
\text { Bulan }\end{array}$ & 22 & $10 \%$ \\
\hline
\end{tabular}

Dari tabel diatas diperoleh $\mathrm{F}_{3}=\{\}$ nilai untuk 3 itemset bernilai 0 atau Himpunan Kosong, karena tidak ada yang memenuhi nilai besaran $\Phi=25$ dan minimum support $30 \%$. selanjutnya melakukan tahap kedua dari analisis asosiasi.

\section{Pembentukan Aturan Asosiasi.}

Berdasarkan hasil tahap pertama yakni pembentukan Pola Frequensi Tinggi ditemukan, maka dilanjutkan dengan membuat Aturan Asosiasi yang 
memenuhi syarat minimum untuk confidence sebesar $70 \%$. nilai minimum confidence aturan asosiatif $\mathrm{A} \rightarrow \mathrm{B}$.

Nilai minimum confidence yang dihitung, hanya untuk pola frekuensi 2 itemset, karena pola 3itemset tidak memenuhi minimum support, oleh karena itu tidak dilanjutkan untuk proses perhitungan confidencenya. Tabel 7 merupakan hasil perhitungan nilai minimum confidence

Tabel 7. Nilai Confidence

\begin{tabular}{|l|l|}
\hline \multicolumn{1}{|c|}{ Aturan } & \multicolumn{1}{c|}{ Confidence } \\
\hline $\mathrm{P}($ Menjarangkan $\mid$ Rendah $)$ & $77 / 164 \times 100 \%=46 \%$ \\
\hline $\mathrm{P}($ Rendah $\mid$ Menjarangkan & $77 / 90 \times 100 \%=85 \%$ \\
\hline $\mathrm{P}($ Menjarangkan $\mid$ Pil $)$ & $74 / 164 \times 100 \%=45 \%$ \\
\hline $\mathrm{P}($ Pil $\mid$ Menjarangkan $)$ & $74 / 93 \times 100 \%=80 \%$ \\
\hline $\mathrm{P}($ Menjarangkan $\mid$ Kondom $)$ & $67 / 164 \times 100 \%=41 \%$ \\
\hline $\mathrm{P}($ Kondom | Menjarangkan $)$ & $67 / 90 \times 100 \%=74 \%$ \\
\hline $\begin{array}{l}\mathrm{P}(\text { Menjarangkan, } \\
\mid \text { Suntik 3 Bulan })\end{array}$ & $80 / 164 \times 100 \%=49 \%$ \\
\hline $\begin{array}{l}\text { P(Suntik 3 Bulan, } \\
\mid \text { Menjarangkan, }\end{array}$ & $80 / 89 \times 100 \%=90 \%$ \\
\hline
\end{tabular}

Aturan asosiasi yang dapat dibentuk berdasarkan nilai minimum confidence ada 4 yaitu :

1. JIka Pendidikan Rendah Maka Usia 17-35 dengan nilai confidence $85 \%$

2. JIka Alat Kontrasepsi Pil Maka Usia 17-35 dengan nilai confidence $80 \%$

3. JIkaAlat Kontrasepsi Kondom Maka Usia 17-35 dengan nilai confidence $74 \%$

4. JIka Alat Kontrasepsi Suntik 3 Bulan Maka Usia 17-35 dengan nilai confidence $90 \%$

Setelah diperoleh nilai Confidence, maka lakukan proses perkalian antara Support dengan Confidence. Hasil perkalian dapat dilihat pada tabel 12 berikut:

Tabel 8. Hasil Perkalian Support dan Confidence

\begin{tabular}{|l|c|}
\hline \multicolumn{1}{|c|}{ Aturan } & \multicolumn{1}{|c|}{$\begin{array}{c}\text { Support } \boldsymbol{x} \\
\text { Confidence }\end{array}$} \\
\hline $\begin{array}{l}\text { JIka Pendidikan Rendah Maka } \\
\text { Usia 17-35 }\end{array}$ & $35 \%$ x 85\%=0,297 \\
\hline $\begin{array}{l}\text { JIka Alat Kontrasepsi Pil Maka } \\
\text { Usia 17-35 }\end{array}$ & $34 \%$ x 80\%=0,272 \\
\hline $\begin{array}{l}\text { JIka Alat Kontrasepsi Kondom } \\
\text { Maka Usia 17-35 }\end{array}$ & $31 \%$ x 74\%=0,229 \\
\hline $\begin{array}{l}\text { Jika Alat Kontrasepsi Suntik 3 } \\
\text { Bulan Maka Usia 17-35 }\end{array}$ & $37 \%$ x $90 \%=0,333$ \\
\hline
\end{tabular}

Berdasarkan hasil perkalian antara support dan confidence, pilihlah hasil perkalian yang paling besar. Hasil paling besar dari perkalian tersebut merupakan rule yang dipakai sebagai acuan bagi akseptor dalam memilih alat kontrasepsi yang akan di gunakan. Rule yang menjadi acuan adalah :

Jika Alat Kontrasepsi Suntik 3 Bulan Maka Usia Ibu 17 - 35 Tahun.

\section{KESIMPULAN}

Penerapan Data Mining Association Rule pada data transaksi pemakaian alat kontrasespi di Puskesmas Dumai Barat menghasilkan 2 Itemset dengan nilai Confidence terbesar $90 \%$ pada Rule atau aturan asosiasi jika Alat Kontrasepsi Suntik 3 Bulan Maka Usia Ibu 17-35 Tahun. Aturan ini merupakan formulasi konsep sehingga dapat dijadikan acuan dalam menetapkan pilihan alat kontrasepsi yang akan digunakan oleh akseptor.

\section{UCAPAN TERIMAKASIH}

Peneliti Mengucapankan terimakasih kepada DRPM KEMENRISTEKDIKTI untuk pendanaan Hibah PDP Tahun Anggaran 2020, Peneliti juga mengucapkan terimakasih kepada Tim Redaksi Jurnal METHOMIKA atas kerjasama yang diberikan hingga Artikel ini Bisa Publish.

\section{DAFTAR PUSTAKA}

Agustin, W., \& Muharmi, Y. (2020). Penerapan Data Mining Menggunakan Algoritma Apriori untuk Menentukan Pola Penyebab Gelandangan dan Pengemis. Jurnal Teknologi Informasi Dan Ilmu Komputer, 7(2), 229.

https://doi.org/10.25126/jtiik.2020721376

BkkbN. (2017). Waspada Program KB Pengguna Alat Kontrasepsi Turun.

Desyanti, D., \& Sari, F. (2019). SATIN - Sains dan Teknologi Informasi Penerapan Algoritma Apriori Terhadap Perawatan Tubuh di Kakiku. Jurnal SATIN - Sains Dan Teknologi Informasi, $5(1)$.

Hasnani, F. H. (2019). Faktor yang Mempengaruhi Akseptor dalam Memilih Alat Kontrasepsi Suntik. Quality: Jurnal Kesehatan, 13(1), 22 27. https://doi.org/10.36082/qjk.v13i1.52

Kusrini, E. taufiq luthfi. (2009). Algoritma Data Mining, Andi Offset, Yogyakarta. Buku, 2009.

Mardiah, M. (2019). Penerapan Data Mining Apriori Pada Persediaan Obat ( Studi Kasus Apotek Rafif Farma Medan ) Mardiah Universitas Nahdlatul Ulama Sumatera Utara, Medan, 
Indonesia Email : mardiahindin23@gmail.com The importance of inventory systems at a pharmacy and the t. ALGORITMA: Jurnal Ilmu Komputer Dan Informatika, 3(2), 115-123.

Parhusip, F. (2019). PEMANFAATAN DATA MINING PENEMPATAN BUKU ( Study Kasus : SMA NEGERI 1 SIDAMANIK ). METHOMIKA: Jurnal Manajemen Informatika \& Komputerisasi Akuntansi, 3(1), 61-65.

Safii, M., \& Trydillah, A. (2019). Implementasi Data Mining Dalam Menentukan Pola Pembelian. METHOMIKA: Jurnal Manajemen Informatika \& Komputerisasi Akuntansi, 3(1), 66-71.

Sari, F. (2017). Implementasi Data Mining Dalam Menganalisis Tingkat Kepuasan Pelanggan Menggunakan Metode Rough Set. Jurnal Buana Informatika, 8(1), 1-10. https://doi.org/10.24002/jbi.v8i1.1071

Sari, F., \& Saro, D. (2018). Implementasi Algoritma C4.5 dalam Menentukan Lokasi Prioritas Penyuluhan Program Keluarga Berencana di Kecamatan Dumai Timur. Jurnal Penelitian Pos Dan Informatika, 8(1), 63-76. https://doi.org/10.17933/jppi.2018.080105

Syahdan, S. Al, \& Sindar, A. (2018). Data Mining Penjualan Produk Dengan Metode Apriori Pada Indomaret Galang Kota. Jurnal Nasional Komputasi Dan Teknologi Informasi (JNKTI), 1(2). https://doi.org/10.32672/jnkti.v1i2.771 